\title{
Activity and Siderophores Production by Rhodotorula spp. Isolates, Potential Antagonists of Botrytis Storage Rot
}

\author{
S. Convertini ${ }^{*}$, Samar A.M.A. Shaarawi** and F. Nigro* \\ *Deptartment of Soil, Plant and Food Sciences, Faculty of \\ Agriculture. University of Bari, Italyand ${ }^{* *}$ Fruit Handling Research \\ Department, Horticulture Research Institute, Agricultural Research \\ Centre, Cairo, Egypt.
}

\begin{abstract}
CREY MOULD, caused by Botrytis cinerea Pers. (ex Fr.), is one $\checkmark$ of the most severe postharvest disease of fruit and vegetables. The use of fungicides is restricted in most countries, and there are problems due to the negative effects they may have on the human and environmental health, and on the selection of fungicide-resistant strains of the pathogen. The use of naturally occurring antagonists to control storage decay and increase product quality represents a practicable alternative to chemical fungicides. However, the mechanisms of action for most of the antagonists investigated have not yet been fully elucidated, because of the difficulties due to the complex interactions between host, pathogen, antagonist, and others microorganisms occurring in the site of interaction. Among the desirable characteristics of microbial antagonists is included the ability for siderophores production. Several phyllosphere yeasts species are known to produce hydroxamate-type siderophores, ironbinding compounds in response to $\mathrm{Fe}$-stress conditions. In this research, more than 100 red yeasts were isolated from the surface of organically and conventionally trained grape berries and leaves, orange fruits, and olive drupes. The ability to produce siderophores was scored qualitatively, and the most active isolates were selected for further biocontrol activity tests against Botrytis storage rot on apple fruits. On the whole, results indicated that isolates R50 and R51, identified as Rhodotorula spp., were the most effective in reducing Botrytis storage rot on apple fruits, although with an intermediate hy droxamate-ty pe siderophores production.
\end{abstract}

Keywords: Grey mould, Red yeasts, Biocontrol agents, Siderophore.

Postharvest decays of fruits and vegetables account for significant levels of yield losses. It has been estimated that about $20-25 \%$ of the harvested fruits and vegetables are decayed by pathogens during postharvest handling, even in developed countries, in developing countries, postharvest losses are often more severe due to inadequate storage and transportation facilities. At the beginning of the 1960s, treatments based on chemical fungicides were the main method to reduce postharvest fruit losses and they gave satisfactory results. However, the 
fungicide option for managing postharvest decays is increasingly limited, in addition, the use of fungicides on fruit after harvest is regulated by different food protection agencies. The intense use of fungicides in the postharvest phase has contributed to the appearance of resistant fungal strains, widespread in packinghouses. Nowadays, fungicide resistance is frequently reported for the main fungal pathogens such as Penicillium, Monilinia, Botrytis, etc. Although the use of synthetic fungicides remains a primary method of controlling postharvest diseases, the global trend appears to be shifting towards reduced use of fungicides, substituting them with alternative means based on physical and biological approaches. However, the great effort made by researchers, documented by many peer-reviewed publications, has been only partially compensated by the appearance on the market of BCAs available for industrial application to control postharvest decays (Sharma et al., 2009 and Liu et al., 2013). The use of naturally occurring antagonistic yeasts and yeast-like fungi to protect fresh fruit and vegetables against postharvest diseases has gained increasing importance. The large body of information now available demonstrates that these microorganisms have characteristics of "ideal antagonist" (Wilson and Wisniewski, 1989), such as the ability to survive under adverse environmental conditions, resistance to chemicals (Droby et al., 1992 and Ippolito et al., 1998), competition for nutrients and space, absence of deleterious metabolites for human health (Ippolito et al., 1997, Piano et al., 1997 and Castoria et al., 1998). Furthermore, preharvest application of yeasts and yeast-like fungi is becoming increasingly popular since this treatment results in the colonization of fruit surfaces and wounds by the biocontrol agents prior to the establishment of postharvest pathogens (Lima et al., 1997, Leibinger et al., 1997 and Ippolito et al., 1998).

A number of different microorganisms including bacteria, filamentous fungi, and yeasts have been isolated and shown to protect fruit against postharvest pathogens, some of them have been utilized to develop commercial products such as Aspire (Candida oleophila strain 182: Ecogen, Inc., Langorne, PA), Bio-Save 10 and 11 (Pseudomonas syringae strain ESC10 and ESC11: EcoScience Corp., Worcester, MA), and Yield Plus (Cryptococcus albidus: Anchor Yeast, Cape Town, South Africa). During the past few decades, promising studies have reported effective preharvest disease control by commercially available biological controlagents and other microorganisms at various developmental stages (Elmer \& Reglinski, 2006, Nally et al., 2012 and Parry et al., 2011). Furthermore, postharvestapplications of several biocontrol agents have also been demonstrated to be effective during storage of table grapes (Romanazzi et al., 2012).

However, despite the success demonstrated with a large number of microbial antagonists, in most cases their performance under large-scale and commercial conditions has been insufficient or inconsistent (Droby et al., 2001, 2009). For biological control to be generally accepted by growers, its performance must be improved to meet the demand for a disease reduction level comparable to that of chemical fungicides. However, such a high level of control could not be

Egypt. J. Hort. Vol. 42, No.1 (2015) 
obtained using few selected biocontrolagents against a large number of pathogens and in different climatic conditions (Droby et al., 1998). Therefore, to maximize the performance of biocontrolagents, it is neces sary to identify new effective biocontrol agents having characteristics suitable for the environment in which they will be used. Furthermore, the availability of a large number of effective biocontrol agents occupying different ecological niches and having different mechanisms of action, could allow the use of two or more microorganisms in a combined strategy (Janisiewicz, 1998 and Spadaro \& Gullino, 2004).

Yeasts appear the most promising biocontrol agents because competition for nutrients, direct interaction with the pathogen and induction of host defense seem to be the main modes of action (Droby and Chaltuz, 1994). These mechanisms make yeast biocontrol agents readily acceptable by consumers since production of antibiotics seems not to be involved. Moreover, yeast activity may be enhanced by integration with cultural methods (Sugar et al., 1994), low fungicide concentrations (Droby et al., 1993 and Lima et al., 2011) or calcium salts (Ippolito et al., 1994). Siderophores produced by different microorganisms have been widely studied as biological agents and it is an alternative to take into account in the control of phytopathogenic microorganisms. Recently there has been an increasing interest in the use of biological control and siderophores produced by several of the fluorescent pseudomonas.

Siderophores are extra cellular, low molecular weight (500 to 1000 Daltons), virtually $\mathrm{Fe}$ (III)-specific ligands produced as scavenging agent in order to combat low iron stress. They are known as a high-affinity chelating agents for ferric iron, and limitation of iron availability is one of the mechanisms by which biocontrol agents' act in inhibiting the growth of phytopathogens ( $\mathrm{Hu}$ and $\mathrm{Xu}, 2011)$. Iron chelating agents, make complex with iron-III with high affinity, facilitate biocontrol by sequestering iron from pathogens, thus limiting their growth (Sullivan and Gara, 1992, Chiriani et al., 1993, Champomier-Veges et al., 1996 and Diaz de Villegas et $a l ., 2002)$. Due to their potentialities in the biological control of phytopathogenic fungi and bacteria their study has been stimulated in recent years (Prema and Selvarani, 2013).

The aim of this study is to evaluate the antagonistic activity of some strains within a collection of the red yeasts highlighting their abilities to survive under cold storage conditions, and to determine the production of siderophores by qualitative and quantitative assays in the is olates showing high potentiality in the antagonistic test.

\section{Material and Methods}

\section{Microorganisms and culture conditions}

The yeasts used in this study, belonging to DiSSPA (Dipartimento di Scienze del Suolo, della Pianta e degli Alimenti, University of Bari, Italy) collection, were isolated from table grape berries and leaves, olive drupes and citrus fruits 
(sweet orange and Clementine) cultivated according to both, organic and conventional management systems.

\section{Red yeasts isolation}

The yeasts have been is olated from both grape bunches closely to maturation period and leaves collected from the plants which have been received routine chemical treatments or from plants that were not subject to any kind of treatments at least for 10 years. Isolates were obtained from grape berries and /or leaves (cv. Italia, Regina and Primitivo), oranges (cv. Valencia) and Clementine fruits, and olives drupes. Plant parts (fruits and /or leaves) were placed in glass bakers containing $100 \mathrm{ml}$ of distilled sterilized water, and shacked four an hour at 250. Subsequently, the washing water were serially diluted (1:10, 1:100, 1:1000, etc.) and $100 \mu \mathrm{l}$ of each concentration were spread on Petri dishes contained NYDA, an agarized selective medium for fungi and yeasts $(10 \mathrm{~g} / \mathrm{l}$ of glucose, $8 \mathrm{~g} / \mathrm{l}$ of Nutrient Broth, $5 \mathrm{~g} / \mathrm{l}$ of Yeast extract, agar $18 \mathrm{~g} / \mathrm{l}$, distilled water $950 \mathrm{ml}, 50 \mathrm{ml}$ of antibiotic solution containing Ampicillin $(250 \mathrm{mg} / \mathrm{l})$ and streptomycin sulphate $(250 \mathrm{mg} / \mathrm{l})$. Petri dishes were then incubated at $24^{\circ} \mathrm{C}$ and monitored after 5-7 days for the growth of red yeasts. After the visual selection based on intensity reddish color, they were transferred to the purity of fresh substrate, identified according to their morphological characters (Van der Walt and Yarrow, 1984) and stored in slants containing NYDA substrate.

\section{Evaluation of the siderophores production by universal CAS assay}

In order to evaluate the involvement of competition for nutrients as a possible mechanism of interaction between red yeast and $B$. cinerea, it was assessed the ability of red yeast used in the tests of antagonism and of those present at the collection of DiSSPA to produce siderophores. This ability to produce siderophores was as sessed qualitatively by the universal CAS assay (Schwyn and Neilands, 1987). This test makes it possible to identify the siderophores exclusively through qualitative survey, regardless of their structure. In the course of the different trials all glassware used in the tests was treated for $12 \mathrm{hr}$ with $\mathrm{HCl} 6 \mathrm{M}$, and thoroughly rinsed with double-distilled water, to remove the occurrence of iron. For the universal CAS assay, the protocol modified by Milagres et al. (1999) was followed, in order to solve the problem due to the toxicity of Chromium-Azurol-S (CAS) to fungi.

The CAS-blue agar was prepared using $60.5 \mathrm{mg}$ of CAS (Dye content 65\%, Aldrich) dissolved in $50 \mathrm{ml}$ of distilled water and mixed with $10 \mathrm{ml}$ of a solution of iron-III $(\mathrm{FeCl} 3 \cdot 6 \mathrm{H} 2 \mathrm{O} 1 \mathrm{mM}$ in $\mathrm{HCl} 10 \mathrm{mM})$. After stirring, to the resulting solution were added slowly $40 \mathrm{ml}$ of an aqueous solution containing $72.9 \mathrm{mg}$ of HDTMA (Hexadecyl trimethyl ammonium bromide, $\geq 99 \%$, Sigma). The solution thus obtained was autoclaved at $121{ }^{\circ} \mathrm{C}$ for $15 \mathrm{~min}$. In parallel, in 750 $\mathrm{ml}$ of distilled water, a suspension containing $15 \mathrm{~g}$ of agar and $30.24 \mathrm{~g}$ of Pipes (BioChemika, appropriate biological buffer, $\geq 99.0 \%$, Fluka) was prepared, to which $12 \mathrm{ml}$ of a $50 \%$ solution (weight/weight) $\mathrm{NaOH}$ were added slowly. The

Egypt. J. Hort. Vol. 42, No.1 (2015) 
resulting suspension was autoclaved at $121{ }^{\circ} \mathrm{C}$ for $15 \mathrm{~min}$. Meanwhile, in Petri dishes (6 cm diameter) $12 \mathrm{ml}$ of PDA were dispensed. After solidification, the substrate was cut by removing a half and, subsequently, in the empty half, $6 \mathrm{ml}$ of CAS-blue agar cooled to $50{ }^{\circ} \mathrm{C}$ were added.

After cooling, the CAS-blue plates were sown with the yeast isolate being evaluated for the production of siderophores by scratching on the boundary line between the two substrates, in the portion of the PDA. For each isolate 5 replications were seeded. The production of siderophores was determined qualitatively, evaluating the development of color change of CAS blue agar using an empirical scale (no, low, medium and high).

In vivo antagonistic activity: biocontrol assays.

Effectiveness of antagonistic yeasts in the control of post-harvest botrytis rot on apple fruits.

In order to test the antagonistic activity of some isolates of red yeast against B. cinerea, a test was carried out on the fruits of apple variety Golden delicious. For the test fruits were selected without apparent defects and uniformity in size. Apples were washed with sodium hypochlorite $(\mathrm{NaClO})$ at $1 \%$ for $2 \mathrm{~min}$, rinsed with distilled water and placed to dry on sterile absorbent paper. Once dried, apples were arranged in PVC trays (4 for each container), divided by separators in cardboard sterilized in an oven. Subsequently, on each fruit were performed 4 wounds (2mm x 2mm), using sterile tips (Lima et al., 1997).

Wounds were inoculated with $40 \mu \mathrm{l}$ of cell suspension of the antagonist at a concentration of $8,5-9 \times 10^{7}$ cells $/ \mathrm{ml}$. The inoculum was prepared by placing the antagonist to grow in a nutrient broth (NYDB, $10 \mathrm{~g} / 1$ of glucose, $8 \mathrm{~g} / 1$ of Nutrient Broth, $5 \mathrm{~g} / \mathrm{l}$ Yeast extract, distilled water $1000 \mathrm{ml}$ ). NYDB flasks were seeded with a loopful of yeast and incubated at $24{ }^{\circ} \mathrm{C}$ for 48 hours over rotary shaker, at $130 \mathrm{rpm}$. After growth, the culture was harvested by centrifugation at $4000 \mathrm{rpm}$ for $15 \mathrm{~min}$ and the pellet re-suspended in $2 \mathrm{ml}$ of sterile distilled water. The concentration of the suspension was determined by cell counts in haemocytometer and adjusted by appropriate dilutions. In the test some isolates from different origins were used.

Afterinoculation of the antagonist in the wounds, the fruits were left to dry for 2 hours at room temperature, so as to promote adhesion of the yeast in the wounds. Subsequently, in the same wound, a conidial suspension of $B$. cinerea $(20 \mu l)$ at a concentration of $4.5 \times 10^{4}$ conidia/ml was inoculated. Fruits inoculated with the antagonist and sterile dis tilled water served as control. The conidial suspension of $B$. cinerea (is olate no. 69), was obtained by collecting in sterile dis tilled water the conidia produced after the growth in PDA plate for 8 days. The concentration of the obtained suspension was determined by haemocy tometer and brought to the desired value $(4.5 \mathrm{x}$ $10^{4}$ conidia / ml) by means of suitable dilutions ( Ljakli and Lepoivre, 1993). 
At the end of inoculation phase, the containers, sealed in plastic envelopes, then were stored at $0 \pm 1^{\circ} \mathrm{C}$ for 20 days, fruits then were held at room temperature up to 6 days and the number of infected wounds and the lesion diameter were determined.

\section{Iron (III) Perchlorate assay}

The quantitative determination of siderophores production was carried out by using the ferric-perchlorate test. This assay is based on the capacity of the hydroxamates to form stable complexes with the iron at low $\mathrm{pH}$ values (Payne, 1994). The yeasts were cultured on plates containing selective PDA, from which one loopful was collected to inoculate $20 \mathrm{ml}$ of the specific culture medium (Table 1). Flasks were incubated at $25 \pm 1^{\circ} \mathrm{C}$ for $24 \mathrm{~h}$, in shaking culture (200 rpm). Subsequently, $99 \mathrm{ml}$ of fresh culture medium were inoculated with $1 \mathrm{ml}$ of the preculture liquid and the whole was incubated at $25^{\circ} \mathrm{C}\left( \pm 1^{\circ} \mathrm{C}\right)$, for 72 hours, on rotary shaker at $200 \mathrm{rpm}$. The culture was then collected by centrifugation at $6000 \mathrm{rpm}, 4{ }^{\circ} \mathrm{C}$, for $10 \mathrm{~min}$. The supernatant was collected and used for the quantitative determination. The assay was carried out by mixing $500 \mu \mathrm{l}$ of supernatant culture medium (as such or appropriately diluted) with $2.5 \mathrm{ml}$ of a solution containing $5 \mathrm{mM} \mathrm{FeCl}_{3}$, and $0.1 \mathrm{M} \mathrm{HClO}_{4}$. The concentration of the hydroxamate-type siderophores was determined by reading the maximum optical density (OD max) at $480 \mathrm{~nm}$ of the resulting solution versus a $500 \mu \mathrm{l}$ of blank solution, similarly prepared from sterile liquid medium. The list of yeast isolates tested according to the protocol previously described, is reported in Table 2.

\section{Experimental design and statistical analysis}

The test was set according to a completely randomized design. For each yeast isolate tested, three replications, each consisting of 4 apples, were used. Four equidistant wounds were performed on the upper zone of each apple. Moreover, for each yeast isolate, three apples were inoculated with the potential antagonist alone, in order to ascertain any pathogenic activity by yeast. Apples inoculated with water were used as a control.

The results obtained were subjected to analysis of variance and the means of the different treatments were compared by the Duncan Multiple Range Test (DMRT) (Gomez and Gomez, 1984).

TABLE 1. Composition of the culture medium used for the production of siderophores.

\begin{tabular}{|c|c|}
\hline \multicolumn{2}{|c|}{ Culture medium for siderophores production } \\
\hline Saccarose & $25 \mathrm{~g} / \mathrm{l}$ \\
\hline$\left(\mathrm{NH}_{4}\right)_{2} \mathrm{SO}_{4}$ & $4 \mathrm{~g} / \mathrm{l}$ \\
\hline $\mathrm{PO}_{4} \mathrm{HK}_{2}$ & $3 \mathrm{~g} / \mathrm{l}$ \\
\hline $\mathrm{Citric}$ acid & $1 \mathrm{~g} / \mathrm{l}$ \\
\hline $\mathrm{MgSO}_{4}$ & $0.08 \mathrm{~g} / \mathrm{l}$ \\
\hline $\mathrm{Zn} \mathrm{SO}_{4}$ & $0.002 \mathrm{~g} / \mathrm{l}$ \\
\hline Adjust the $\mathrm{pH}$ to 6.8 and sterilized (whole cycle autoclave). \\
\hline
\end{tabular}

Egypt. J. Hort. Vol. 42, No.1 (2015) 
ACTIVITY AND SIDEROPHORES PRODUCTION BY RHODOTORULA SPP. .459

TABLE 2. List of red yeasts subjected to ferric perchlorate assay with its area of origin and isolation matrix.

\begin{tabular}{|c|c|c|}
\hline $\begin{array}{l}\text { Index of } \\
\text { collection }\end{array}$ & Yeast & $\begin{array}{lll}\begin{array}{l}\text { Isolation } \\
\text { province }\end{array} & \text { Matrix, locality and } \\
\end{array}$ \\
\hline R.103 & Rhodotorula glutinis & Olive drupes, Larino, Campobasso \\
\hline R.103/2 & Rhodotorula glutinis/2 & Olive drupes, Larino, Campobasso \\
\hline R.50 & Rhodotorula spp. & Grapes, cv. Regina, Andria, Bari \\
\hline R.44 & Rhodotorula spp. & Grapes, cv. Italia, Rutigliano, Bari \\
\hline R.51 & Rhodotorula spp. & Grapes, cv. Regina Andria, Bari \\
\hline R.28 & Rhodotorula spp & Citrus, cv. Valencia late, Taranto \\
\hline R.86 & Rhodotorula spp & $\begin{array}{l}\text { Grape leaves, cv. Italia, Rutigliano, } \\
\text { Bari }\end{array}$ \\
\hline R.45 & Rhodotorula spp & Grape berries, \\
\hline R.43 & Rhodotorula spp & Grape berries \\
\hline R.100 & Rhodotorula spp & Oranges, cv. Valencia late, CRB \\
\hline R.29 & Rhodotorula spp & Oranges cv. Valencia \\
\hline R.55 & Rhodotorula spp & Grapes, cv Regina, Andria, Bari \\
\hline R.97 & Rhodotorula spp & Oranges, cv. Valencia late CRB \\
\hline L.47 & $\begin{array}{l}\text { Aureobasidium } \\
\text { pullulans }\end{array}$ & $\begin{array}{l}\text { Reference isolates, for space and } \\
\text { nutrient competition (Ip polito } \text { et al., } \\
\text { 2000) }\end{array}$ \\
\hline L.672 & $\begin{array}{l}\text { Aureobasidium } \\
\text { pullulans }\end{array}$ & $\begin{array}{l}\text { Reference isolates, for space and } \\
\text { nutrient competition }\end{array}$ \\
\hline
\end{tabular}

\section{Results}

Qualitative evaluation of siderophores production by different isolates of epiphytic Rhodotorula spp. using universal Chrome Azurol S (CAS) assay: Detection of siderophore production

Red yeasts isolates listed in Table 3 were tested for their ability to produce siderophores by using the universal assay of CAS-blue agar (Fig. 1). Different red-yeast isolates showed different levels of siderophores production (Fig. 2). Isolates were grouped in four different groups (none, low, medium, and high siderophore production) according to the level of discoloration induced on CAS blue agar plates (Table 3). The color change in the CAS-blue agar plates indicated that microorganisms reacted in different manners to the assay (Milagres et al., 1999). 
TABLE 3. Qualitative evaluation of siderophores production by different isolates of epiphytic Rhodotorula spp. Isolates were grouped according to the level of discoloration induced on CAS -blue agar plates.

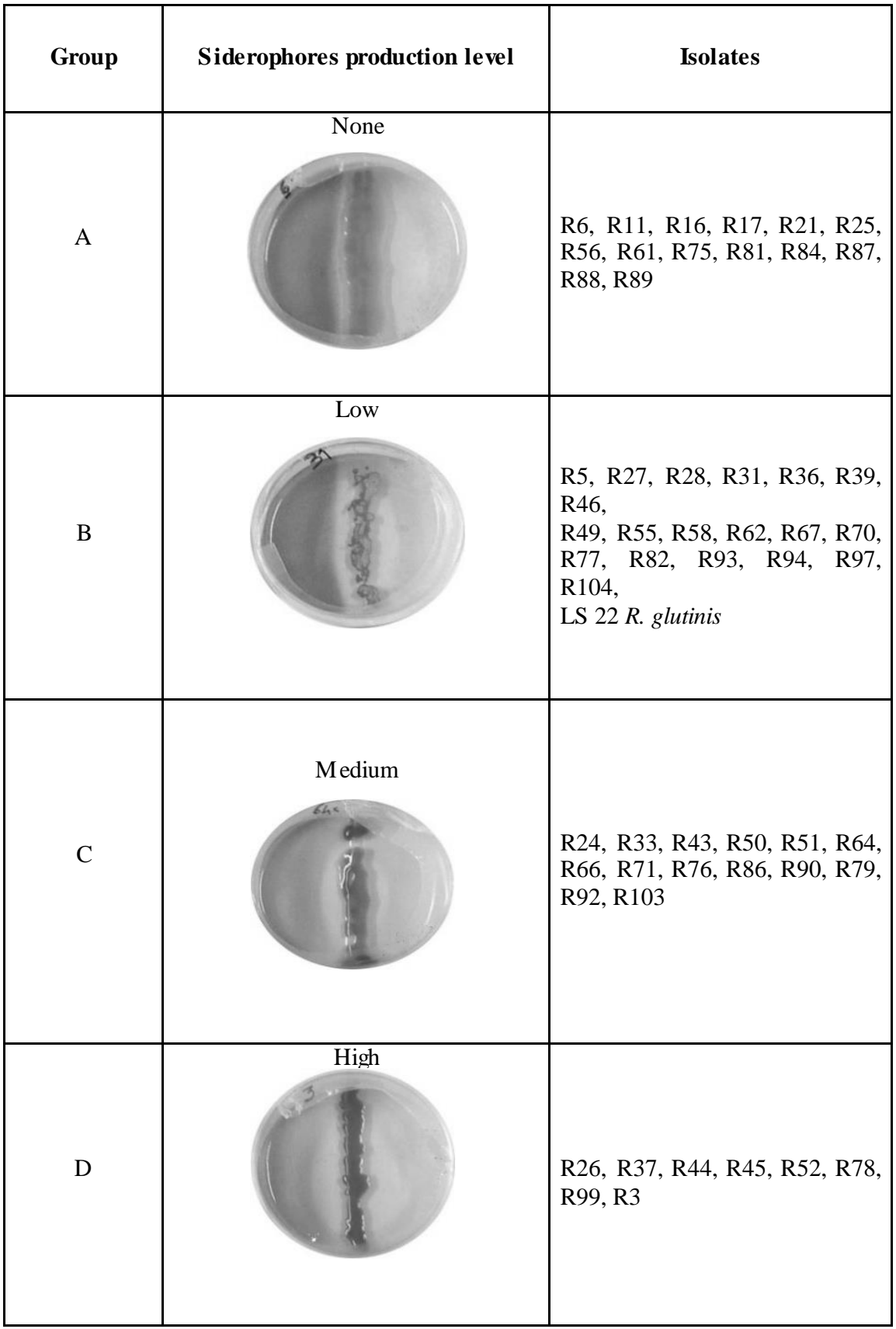

Egypt. J. Hort. Vol. 42, No.1 (2015) 


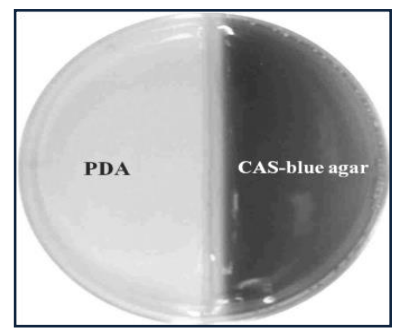

Fig. 1. Example of the Petri dish containing the substrate CAS -blue agar used to test the ability of the isolates to produce siderophores.

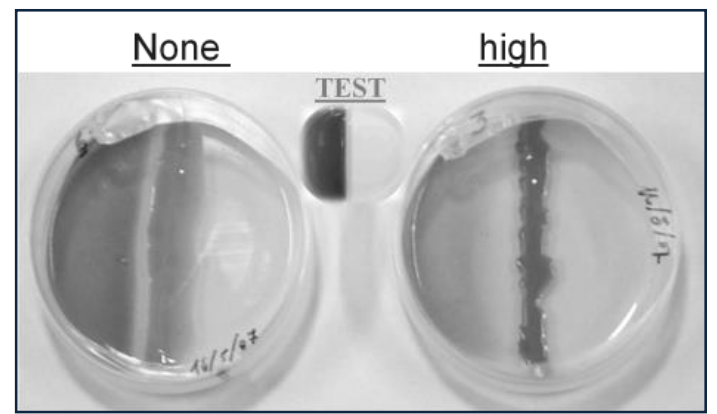

Fig. 2. Comparison of the production of siderophores between two red yeasts isolates.

Efficacy of the antagonistic yeasts in controlling Botrytis rot on apples:

in-vivo assay. Yeast isolates were evaluated for their efficacy as biocontrol agents against Botry tis rot on apple fruits. After 20 days of cold storage at $0^{\circ} \mathrm{C}\left( \pm 1^{\circ} \mathrm{C}\right)$, followed by six days shelf life at room temperature, results indicated that some of the tested yeasts induced significant reduction on both rot percentage as well as lesion diameter $(\mathrm{mm})$, as compared to untreated control (Fig. 3). Isolates named R43, R50, R51, and 86, belonging to the $\mathrm{C}$ group and recognized as medium rates siderophores producer on CAS assay, showed the highest and significant efficacy in reducing both rot percentage and lesion diameter as comp ared tootherisolates and the untreated control. Whereas, isolates R26, R44, R45, R52, R78, R99, and R3 induced significant reduction of the lesion diameter only, as compared to the untreated control.

\section{Perchlorate ferric assay.}

The amounts of siderophores excreted into the culture medium were determined by using the iron (III) perchlorate assay. High concentrations of hydroxamate-type siderophores were obtained with isolates R103, R103/2, and L47 which were used as references isolates (Fig. 4). Isolats R50, R51, and R99 showed significantly higher siderophores production as compared to the remaining is olates. Conversely, is olates R43 and R86 which were among the best in the qualitative test, showed a lower siderophore production (Fig. 4). 

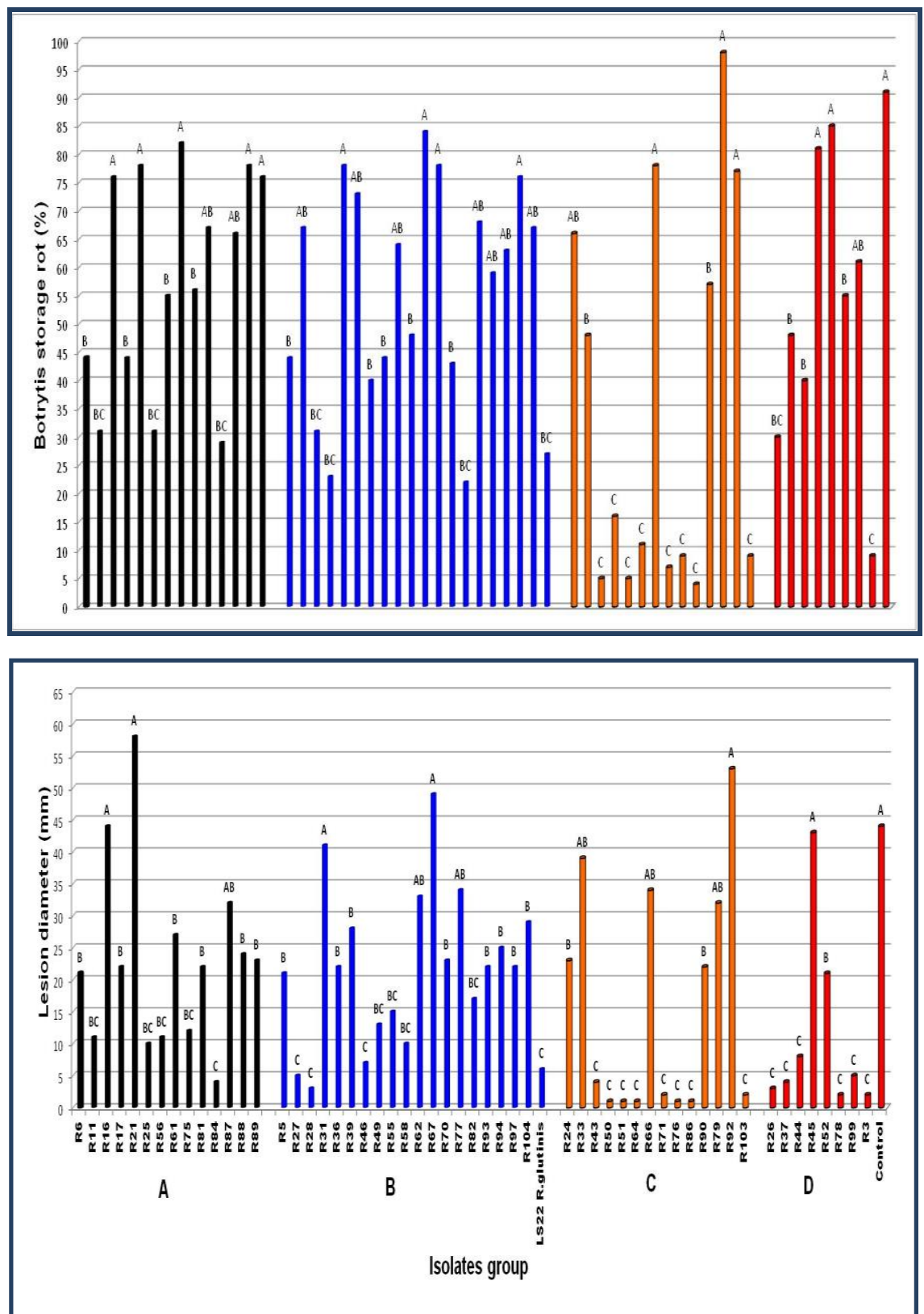

Fig. 3. Activity of different Rhodotorula spp. isolates on the reduction of Botrytis storage rot incidence (upper panel) and lesion diameter (lower panel) on apple fruits, after 20-days storage at $0 \pm 1^{\circ} \mathrm{C}$ and 6 days shelf life at room temperature. Bars marked with the same letters are not statistically different according to the DMRT $(P \leq 0,01)$. 


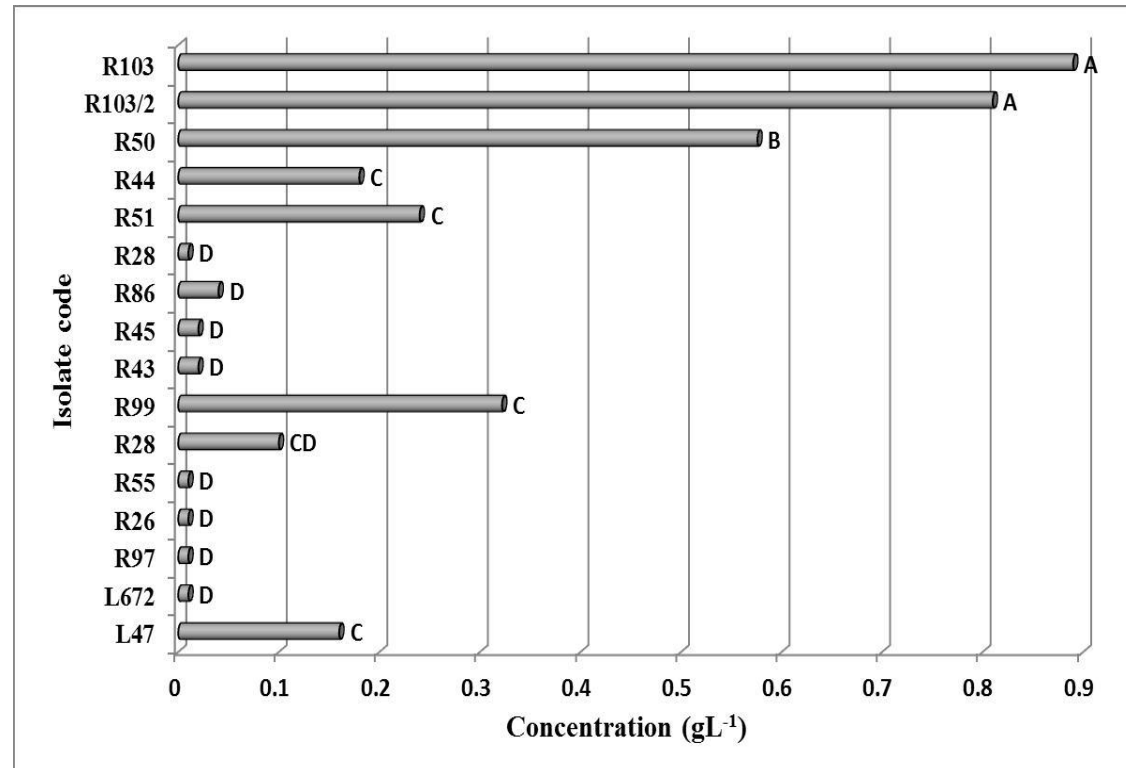

Fig. 4. Quantitative determination of hydroxamate-type siderophores production by different isolates of Rhodotorula spp. In the test the isolates R103 of $R$. glutinis, already known for its production of siderophores, and the antagonistic isolates L47 and L672 of A. pullulans, characterized for their mode of action based on the competition for space and nutrients, were also included. Bars marked with the same letters are not statistically different according to the DMRT $(P \leq 0,01)$.

\section{Discussion}

Most of the methods used to determine the siderophores production are carried out on the microorganism culture supernatant, because siderophores are found there, with the exception of the cell wall-associated mycobactins (Calvente et al., 2001a). With respect to the assays for determining siderophores, they can be either unspecific or based on chemical or biological properties of the siderophores (Payne, 1994). In this research CAS-blue agar assay has been used to screen a number of collected is olates of Rhodotorula spp. and to evaluate their ability to produce siderophores. Isolates were then categorized according to their capability of siderophores production in four groups: A (no production), B (low), C (medium) and D (high production). Although the universal assay on CAS-blue agar, developed by Schwyn and Neilands (1987), is considered as the most used and unspecific test, a further confirmation of the obtained data is neces sary with in vivo assay. Our results showed a significant reduction in either decay percentage and lesion diameter by the strains R50 and R51, thus suggesting that rhodotorulic acid based-siderophore produced by these is olates has an effective role in the control of B. cinerea. Similar results have been reported by Calvente et al. (1999), who 
demonstrated that rhodotorulic acid, a hydroxamate-type siderophore produced by Rhodotorula glutinis strains, improves the biological control of blue rot caused by Penicillium expansum and gray mould in harvested apples. Rhodotorulic acid, a siderophore produced by yeasts belonging to the genus Rhodotorula, has also shown ability to inhibit spore germination of various plant pathogens including $B$. cinerea, (Calvente et al., 2001b), since conidia require a large intake of iron for germinating (Charlang et al., 1981). In addition, Calvente et al. (2001a), mentioned that yeasts produce hydroxamate-type siderophores (iron-binding compounds) in response to Fe-stress conditions which are important to the biocontrol of postharvest diseases of apple and pears. In iron(III)-perchlorate assay, isolates R50, R51 showed appreciable results which were in accordance with the results observed on other chemical or biological test, however, isolates R43 and R86 although showing a high production of siderophores in the qualitative test (CASagar), resulted poor siderophores producer when tested with the quantitative one. Although the iron(III)-perchlorate assay provides not only a means of detection but also considerable information about the structure of the compound (Calvente et al., 2001a), Paul and Dubey (2015) reported that siderophores of the same type can show different absorbance maximum, thus leading to the hypothesis that these compound could be structurally different siderophores.

In conclusion, using CAS-blue agar and iron (III)-perchlorate assays it was possible to carry out a preliminary screening for hydroxamic-based siderophores production in a collection of Rhodotorula isolates originally living on different fruit surfaces. Moreover, in-vivo assays were useful to identify potential antagonists of post-harvest gray mould on apple fruits. Isolates R43 and R86 demonstrated high siderophores production in the qualitative test (CAS-blue agar), whereas they resulted poor producers in the quantitative test for hydroxamate-type siderophores production. This leads to the necessity to develop and use further tests, enabling the quantification and characterization of other forms of siderophores. Two Rhodotorula spp. Isolates, R50 and R51, demonstrated high antagonistic activity and a good survival rate during the cold storage (Nigro et al., unpublished). Further trials on different fruit species and varieties will provide data to confirm the antagonistic efficacy of these two new biocontrol agents producing siderophores.

\section{References}

Calvente, V., de Orellano, M.E., Sansone, G., Benuzzi, D. and Sanz de Tosetti, M.I., (2001a) A simple agar plate assay for screening siderophore producer yeasts. Journal of Microbiological Methods, 47(3), 273-279.

Calvente, V., Benuzzi, D. and Sanz de Tosetti, M.I. (1999) Antagonistic action of siderophores from Rhodotorula glutinis upon the postharvest pathogen Penicillium expansum. Int. Biodeterior. Biodegrad., 43, 167-172.

Calvente, V., de Orellano, M.E., Sansone, G., Benuzzi, D. and S anz de Tosetti, M.I., (2001 b) Effect of nitrogen source and $\mathrm{pH}$ on siderophore production by Rhodotorula strains and their application to biocontrol of phytopathogenic moulds. J. Ind. Microbiol. Biotechnol., 26 (4), 226-229.

Egypt. J. Hort. Vol. 42, No.1 (2015) 
Castoria, R., De Curtis, F., Lima, G., Pacifico, S. and De Cicco, V. (1998) Mechanisms of action involved in the antagonism of Aureobasidium pullulans against postharvest pathogens. J. Plant Path., 80 (3) p. 253 abst.

Champomier-Veges, M.C., Stintzi, A. and Meyer, J.M. (1996) Acquisition of iron by the non-siderophore producing Pseudomonas fragi. Microbiology, 142, 1191-1199.

Charlang, G., Bradford, N., Horowitz, N. and Horowitz, R. (1981) Cellular and extracellular siderophores of Aspergillus nidulans and Penicillium chrysogenum. Mol. Cell. Biol., 1, 94-100.

Chiriani, L., Tobacchioni, S. and Bevivino, A. (1993) Interactions between rhizosphere microorganisms under iron limitation. Arch. Microbiol., 160, 68-73.

Díaz de Villegas M.E., Villa P.M. and Frías A. (2002) Evaluation of the siderophores productionby Pseudomonas aeruginosa PSS. Revista Latinoamericana de Microbiología, 44 (3-4), 112-117.

Droby, S, Cohen, L. Daus, A., Weiss, B., Horev, B., Chalutz, E., Katz, H., Keren Tzur, M. and Shachnai, A. (1998) Commercial testing of Aspire: a yeast preparation for the biological control of postharvest decay of citrus. Biological Control, 12, 97-101.

Droby, S. and Chalutz, E. (1994) Mode of action of biocontrol agents of postharvest diseases. In: Biological Control of Postharvest Diseases - Theory and Practice, Wilson, C.L. and Wisniewski, M.E. (Ed.), pp 63- 75, CRC Press, Boca Raton, Florida.

Droby, S., Chalutz, E., Wilson, C.L. and Wisniewski, M.E. (1992) Biological control of postharvest diseases: a promising alternative to the use of synthetic fungicides. Phytoparasitica, 20, 149-153.

Droby, S., Chalutz, E., Wilson, C.L. and Wisniewski, M.E. (1993) Biological control of postharvest diseases: a promising alternative to the use of synthetic fungicides. Phytoparasitica, 20,149-153.

Droby, S., Cohen, L., Wiess, B., Daus, A. and Wisniewski, M. (2001) Microbial control of postharvest diseases of fruits and vegetables - current status and future outlook. Acta Horticulturae, 553, 371-376.

Droby, S., Wisniewski, M., Macarisin, D. and Wilson, C. (2009) Twenty years of postharvest biocontrol research: is it time for a new paradigm? Postharvest Biol. Technol., 52, 137-145.

Elmer, P.A.G. and Reglinski, T. (2006) Biosuppression of Botrytis cinerea in grapes. Plant Pathology, 55, 155-177.

Gomez and Gomez (1984) "Statistical Procedures for Agricultural Research", John Wiley and Sons, New York, 680p.

Hallmann, J., Qualt-Hallmann, A, Mahaffee, W.F., and Kloepper J.W. (1997) Bacterial endophytes in agricultural crops. Can. J. Microbiol., 43, 895-914. 
Hu, Q-P. and Xu, J-G. (2011) A simple double-lay ered chrome azurol S agar (SD-CASA) plate assay to optimize the production of siderophores by a potential biocontrol agent Bacillus. African Journal of Microbiology Research, 5 (25), 4321-4327.

Ippolito, A., El-Ghaouth A., Wilson C.L. and Wisniewski, M. (2000) Control of postharvest decay of apple fruit by Aureobasidium pullulans and induction of defense responses. Postharvest Biology and Technology, 19(3), 265-272

Ippolito, A., Lima, G., Nigro, F., Linsalata, V. and Cascarano, N. (1994) Influenza del calcio sulla mufa grigia dell'uva da tavola e sull'attivita di microrganismi antagonisti del patogeno. Italus Hortus, 1, 36-41.

Ippolito, A., Nigro, F., Lima, G., Romanazzi, G. and Salerno, M. (1998) Attivita`di Aureobasidium pullulans con l'aggiunta di gomma xantano nella lotta contro il marciume acido e botritico dell'uva da tavola. In Proceedings VI Convegno annuale S.I.Pa.V., 17-18 Settembre, 12. Campobasso, Italy, p. 26.

Ippolito, A., Nigro, F., Romanazzi, G. and Campanella, V. (1997) Field application of Aureobasidium pullulans against Botrytis storage rot of strawberry. In: Nonconventional Methods for the Control of Post- Harvest Disease and Microbiological Spoilage, Bertolini, P., Sijmons, P.C., Guerzoni, M.E., Serra, F. (Ed.), Workshop Proceedings COST 914-COST 915. Bologna, Italy, pp. 127-133.

Janisiewicz, W. (1988) Biocontrol of postharvest diseases of apples with antagonist mixtures. Phytopathology, 78, 194-198.

Leibinger, W., Breuker, B., Hahn, M. and Mendgen, K. (1997) Control of postharvest pathogens and colonization of the apple surface by antagonistic microorganisms in the field. Phytopathology, 87, 1103-1110.

Lima, G., Castoria, R., De Curtis, F., Raiola, A., Ritieni, A. and De Cicco. V. (2011) Integrated control of blue mould using new fungicides and biocontrol yeasts lowers levels of fungicide residues and patulin contamination in apples. Postharvest Biology and Technology, 60, 164-172.

Lima, G., Ippolito, A., Nigro, F. and Salerno, M. (1997) Effectiveness of Aureobasidium pullulans and Candida oleophila against postharvest strawberry rots. Postharvest Biol. Technol., 10, 169-178.

Liu, J., S ui, Y., Wisniewski, M., Droby, S.and Liu Y. (2013) Utilization of antagonistic yeasts to manage postharvest fungal diseases of fruit. Int. J. Food Microbiol., 167, 153-160.

Ljakli, M.H. and Lepoivre, P. (1993) Biological control of postharvest Botrytis cinerea and Penicillium on apples. IOBC/WPRS Bull. 16, 106-110.

Egypt. J. Hort. Vol. 42, No.1 (2015) 
Milagres, A.M.F., Machuca, A. and Napoleao, D. (1999) Detection of siderophore production from several fungi and bacteria by a modification of chrome azurol $\mathrm{S}$ (CAS) agar plate assay. J. Microbiol. Methods, 37(1), 1-6.

Nally M.C., Pesce V.M., Maturano Y.P., Muñoz C.J., Combina M., Toro M.E., Castellanos de Figueroa L.I. and Vazquez F. (2012) Biocontrol of Botrytis cinerea in table grapes by non pathogenic indigenous Saccharomyces cerevisiae yeasts isolated from viticultural environments in Argentina. Postharvest Biology and Technology, 64 (1), 40-48.

Neilands, J. B. and Leong, S. A. (1986) Siderophores in Relation to Plant Growth and Disease Annual Review of Plant Physiology, 37, 187 -208.

Parry, M.A.J, Reynolds M., Salvucci M.E., Raines C., Andralojc P.J., Zhu X-G, Price G.D., Condon A.G. and Furbank R.T. (2011) Raising yield potential of wheat. II. Increasing photosynthetic cap acity and efficiency. Journal of Experimental Botany, 62, 453-467.

Paul, A. and Dubey, R. (2015) Characterization of protein involved in nitrogen fixation and estimation of co-factor. International Journal of Current Research in Biosciences and Plant Biology, 2 (1), 89-97.

Payne, S. (1994) Detection, isolation and characterization of siderophores. Methods in Enzymology, 235, Academic Press, NY, pp. 329-344.

Piano, S., Neyrotti, V., Migheli, Q. and Gullino, M.L. (1997) Biocontrol capability of Metschinkowia pulcherrima against Botrytis postharvest rot of apple. Postharvest Biol. Technol., 11, 131-140.

Prema, P. and Selvarani, M. (2013) Microbial Siderophore as a Potent Biocontrol Agent for Plant Pathogens. International Journal of Scientific Research, 2 (7), 521-523.

Romanazzi, G., Lichter, A., Mlikota Gabler, F. and Smilanick, J.L. (2012) Recent advances on the use of natural and safe alternatives to conventional methods to control postharvest gray mold of table grapes Postharvest Biology and Technology, 63, 141-147.

Schwyn, B. and Neilands, J.B. (1987) Universal chemical assay for the detection and determination of siderophores. Anal. Biochem., 160, 46-56.

Sharma, R.R., Singh, D. and Singh, R. (2009) Biological control of postharvest diseases of fruits and vegetables by microbial antagonists: a review. Biol. Control., 50, 205-221.

Spadaro, D. and Gullino, M.L. (2004) State of the art and future prospects of the biological control of postharvest fruit diseases. Int. J. Food Microbiol., 91, 185-194.

Sugar, D., Roberts, R.G. Hilton, R.J., Righetti, T.L. and Sanchez, E.E. (1994) Integration of cultural methods with yeast treatment for control of postharvest fruit decay in pear. Plant Disease, 78, 791-795. 
Sullivan, D.J. and Gara F.O. (1992) Traits of fluorescent Pseudomonas spp. involved in suppression of plant root pathogens. Microbiol. Rev., 56, 662-676.

Van der Walt, J.P. and Yarrow, D. (1984) Methods for the isolation, maintenance, classification and identification of yeasts. In: The yeasts: a taxonomic study, $3^{\text {rd }}$ ed., (pp. 45104) Kreger-van Rij NJW (Ed.), Elsevier Science Publishers B.V., Amsterdam, Netherlands.

Wilson, C.L. and Wisniewski,M. (1989) Biological control of postharvest diseases of fruits and vegetables: an emerging technology. Annual Review of Phytopathology, 27, 425-441.

(Received 6/10/2014;

accepted 8/2/2015)

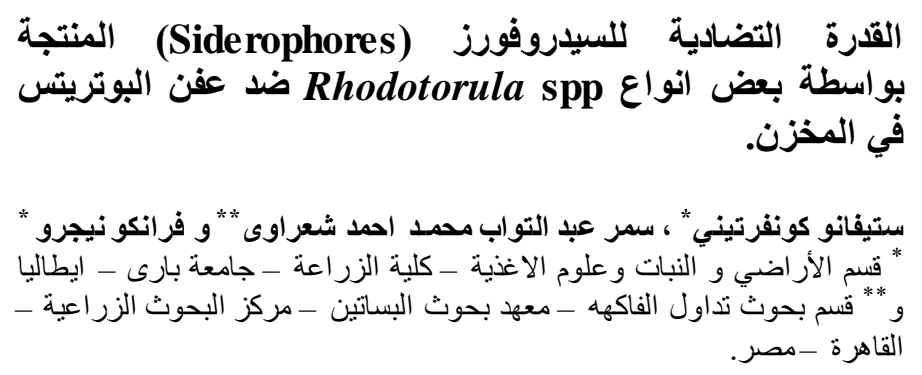

يعتبر العفن الرمادي المتسبب عن فطر البوتريتس احد اهم امر اض ما بعد الحصاد الدياد

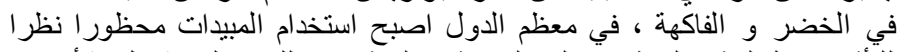

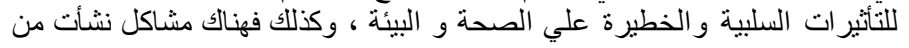

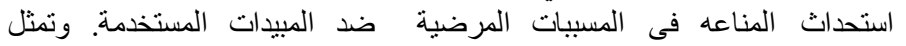

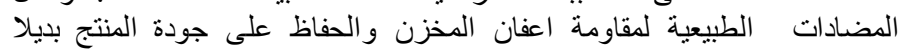

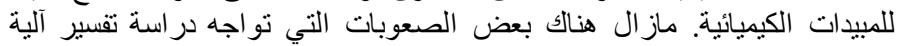

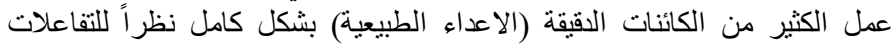

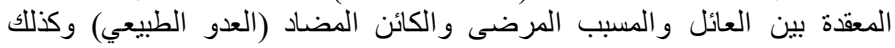

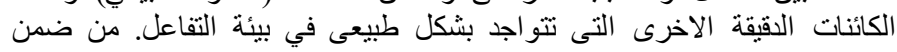

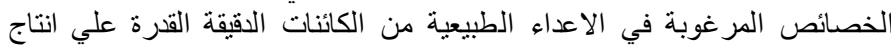

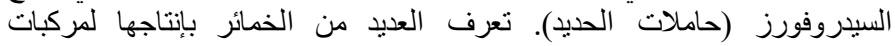

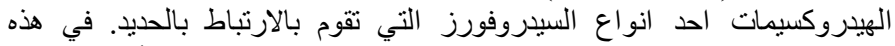

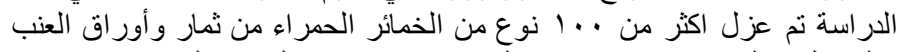

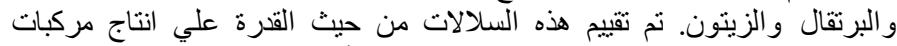

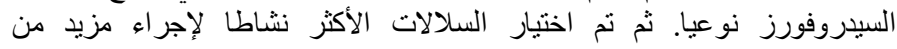

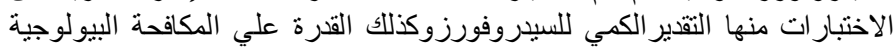

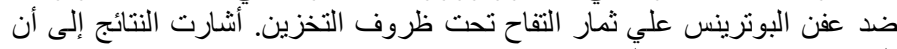

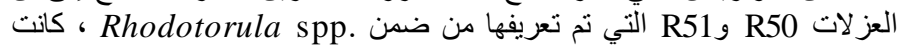

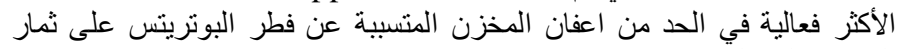

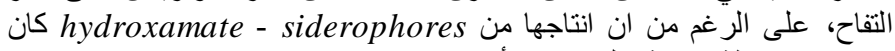

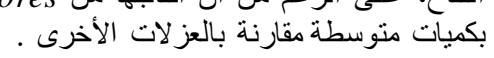

Siderophores ، الكلمات الدالة: العفن الرمادي ، الخمائر الحمر اءه ، المكافحة الحيوية

Egypt. J. Hort. Vol. 42, No.1 (2015) 